\title{
The serodiagnosis of infection with Salmonella typhi
}

\author{
H Chart, J S Cheesbrough, D J Waghorn
}

\begin{abstract}
BackgroundlAims-The serodiagnosis of infection with Salmonella typhi, using the Widal agglutination assay, relies on patients' antibodies to the $\mathrm{O}=9,12$ lipopolysaccharide (LPS) antigens, $\mathrm{H}=\mathrm{d}$ flagellar antigens, and the $V i$ capsular antigens. $A$ $V i$ agglutination titre of $>1 / 40$ has traditionally been regarded as indicative of recent infection with $S$ typhi. In this study, 91 sera were used to assess the reliability of the Widal agglutination assay based on antibodies to the Vi antigens.
\end{abstract}

Methods-The Widal agglutination assay was carried out using protocols established by the Central Public Health Laboratory, Colindale. Antibodies to the Vi capsular antigen were detected using a standard preparation of $S$ typhi, ViI Bhatnagar variant strain (S typhi, ViI). Sera used in the study comprised 73 from patients who were culture positive for $S$ typhi, 10 from patients who were culture positive for other species of Salmonella not expressing a Vi antigen (namely, $\boldsymbol{S}$ javiana, S enteritidis, S typhimurium, $S$ stanley, S saint paul, $S$ bareilly, or $S$ mbandaka), and eight from healthy blood donors.

Results-Agglutination titres of $\geqslant 1 / 40$ were detected to $S$ typh $i$ ViI in 69 of 73 sera from patients with typhoid, although 27 of these also agglutinated an unrelated control antigen. The Widal assay also detected significant amounts of agglutinating antibodies to $S$. typhi ViI in all eight control sera and seven sera from patients infected with $S$ bareilly, $S$ enteritidis, S javiana, $S$ mbandaka, $S$ saint paul, and $S$ stanley. Conclusions-Agglutinating antibodies to the Vi antigen can be detected by the Widal assay, but even with the appropriate control antigens the results were unreliable. The serodiagnosis of infections with $S$ typhi should be based on the detection of antibodies to both the $O=9,12$ LPS antigen and the $\mathrm{H}=\mathrm{d}$ flagellar antigen by immunoblotting, and should not use the Vi antigen-based Widal assay. Conclusions should be made in the light of patients' clinical details and any knowledge of previous immunisation for typhoid.

(F Clin Pathol 2000;53:851-853)

Keywords: Salmonella typhi; Widal assay; O=9,12 lipopolysaccharide antigen; $\mathrm{H}=\mathrm{d}$ flagellar antigen

Salmonella typhi continues to be a major public health problem in developing countries, and although the incidence of typhoid is lower in northern Europe and North America, cases occur among travellers returning from endemic areas. Although the diagnosis of typhoid is confirmed by culturing $S$ typhi from specimens of blood, stool, urine, or occasionally bone marrow, in certain cases, especially after antibiotic treatment, $S$ typhi might not be isolated, and the diagnosis relies on a combination of clinical and epidemiological features. In such cases, the detection of antibodies to $S$ typhi might be the only way of confirming the clinical diagnosis.

The antigenic structure of $S$ typhi is [Vi], 9, $12: \mathrm{d},{ }^{1}$ and infection with this organism may result in the production of serum antibodies to the $\mathrm{O}=9,12$ somatic, the $\mathrm{H}=\mathrm{d}$ flagellar, and the "Vi" capsular antigens. Classically, the Widal agglutination test has been used to detect patients' antibodies to these antigens. ${ }^{2}$ Concerns about the performance of this assay resulted in the introduction of the definitive Widal assay issued by the Medical Research Council's standards laboratory at Oxford, ${ }^{2}$ which used strictly standardised antigens and methods. Despite this, interpretation of the Widal test has been problematic-for example, antibody titres considered as clinically relevant against $\mathrm{O}=9,12$ lipopolysaccharide (LPS) antigens have been set at values varying from $1 / 20,{ }^{3}$ $1 / 40,{ }^{45} 1 / 80,{ }^{6}$ to $1 / 160$.

In view of these problems, the techniques of sodium dodecyl sulphate polyacrylamide gel electrophoresis (SDS-PAGE) and immunoblotting were investigated and shown to be more sensitive and specific than the Widal agglutination assay for detecting antibodies to $\mathrm{O}=9,12$ LPS and $\mathrm{H}=\mathrm{d}_{\text {flagellar antigens. }}{ }^{8-10}$

The standard Vi agglutination assay uses formalin fixed bacteria prepared from a standard strain of $S$ typhi ViI, a variant strain of $S$ typhi lacking normal LPS and flagellar antigens, originally isolated from a carrier in Denmark. ${ }^{11}{ }^{12}$ For the routine Widal assay performed in the laboratory of enteric pathogens, a serum agglutination titre of $\geqslant 1 / 40$ denotes high concentrations of antibodies to the $\mathrm{Vi}$ antigen, and is considered indicative of infection with $S$ typhi.

In our study, sera from three groups of people were used to compare the established Widal assay based on Vi antigens, with the techniques of SDS-PAGE and immunoblotting, and dot blotting. The sera were from: (1) patients who were either faecal or blood culture positive for $S$ typhi; (2) patients who were faecal culture positive for other species of salmonella; and (3) healthy controls. 


\section{Methods}

BACTERIA

The strain of $S$ typhi ViI used in our study expressed $\mathrm{Vi}$ antigen, but produced reduced amounts of LPS antigens and no flagella. ${ }^{112} \mathrm{~A}$ strain of $S$ godesburg (JT 689) with $\mathrm{O}=30$ LPS antigen, $\mathrm{H}=\mathrm{g}$, $\mathrm{m}$ flagellar antigens, but without $\mathrm{Vi}$ antigen was used as a negative control. A strain of $S$ enteritidis (P132344) was used for the preparation of LPS with 9,12 antigens. $^{8-10}$ Bacteria were grown on nutrient agar $\left(37^{\circ} \mathrm{C}\right.$, 16 hours), from Dorset's egg agar slopes stored in the laboratory of enteric pathogens.

SERA

Seventy three sera were tested from patients who were culture positive for $S$ typhi. ${ }^{9}$ The patients were all from the Infectious Disease Hospital, Kuwait. ${ }^{9}$ Seventy two of these sera were known to contain antibodies to the 9,12 LPS antigens, ${ }^{9}$ and 48 had antibodies to $\mathrm{H}=\mathrm{d}$ flagellar antigens. ${ }^{9}$ Sera were also available from 10 patients (table 1) who were culture positive for $S$ javiana (one), $S$ enteritidis (four), $S$ typhimurium (one), S stanley (one), S saint paul (one), $S$ bareilly (one), and $S$ mbandaka (one). ${ }^{1314}$ Eight sera were obtained from healthy controls from the UK, but their typhoid vaccination details were not known. All sera were stored at $-30^{\circ} \mathrm{C}$ until used.

\section{Vi ANTIGEN}

$\mathrm{Vi}$ antigen was prepared by digestion of $S$ typh $i$ ViI with proteinase $\mathrm{K}$ (Sigma Chemical Co Ltd, Poole, Dorset, UK) as for the preparation of LPS, ${ }^{8-10} 1314$ and the enzyme was heat inactivated before SDS-PAGE and dot blotting. ${ }^{15}$

WIDAL AGGLUTINATION

The agglutination assay was performed based on the routine procedures used in the laboratory of enteric pathogens. The standard strain of $S$ typhi ViI was grown in a $100 \mathrm{ml}$ medical

Table 1 Agglutinating antibodies to Salmonella typhi ViI and S godesburg in sera from patients culture positive with Salmonella spp

\begin{tabular}{lllll}
\hline & & \multicolumn{2}{l}{ Agglutination titre } \\
\cline { 4 - 5 } Organism isolated & LPS antigens & $\begin{array}{l}\text { Flagellar } \\
\text { antigens }\end{array}$ & Styphi ViI & S godesburg \\
\hline S bareilly & $6,7,14$ & $\mathrm{y}$ & $>1 / 40 \dagger$ & $1 / 40$ \\
S enteritidis & $1,9,12$ & $\mathrm{~g}, \mathrm{~m}$ & $>1 / 40 \dagger$ & $<1 / 40$ \\
S enteritidis & $1,9,12$ & $\mathrm{~g}, \mathrm{~m}$ & $>1 / 40 \dagger$ & $1 / 40$ \\
S enteritidis & $1,9,12$ & $\mathrm{~g}, \mathrm{~m}$ & $<1 / 40$ & $<1 / 40$ \\
S enteritidis & $1,9,12$ & $\mathrm{~g}, \mathrm{~m}$ & $<1 / 40$ & $<1 / 40$ \\
S javiana & $1,9,12$ & $1, \mathrm{z} 28$ & $>1 / 40 \dagger$ & $<1 / 40$ \\
S mbandaka & $6,7,14$ & $\mathrm{z} 10$ & $>1 / 40 \dagger$ & $>1 / 40$ \\
S saint paul & $1,4,5,12$ & $\mathrm{e}, \mathrm{h}$ & $>1 / 40 \dagger$ & $1 / 40$ \\
S stanley & $1,4,5,12,27$ & $\mathrm{~d}$ & $>1 / 40 \dagger$ & $>1 / 40$ \\
S typhimurium & $1,4,5,12$ & $\mathrm{i}$ & $<1 / 40$ & $<1 / 40$ \\
\hline
\end{tabular}

†Indicative of infection with $S$ typhi.

LPS, lipopolysaccharide.

Table 2 Agglutinating antibodies to Salmonella typhi ViI and S godesburg in sera from patients culture positive with $S$ typhi and normal controls

\begin{tabular}{llll}
\hline \multicolumn{2}{l}{ Agglutination titre } & Patients $(n=73)$ & Healthy controls $(n=8)$ \\
\hline $1 / 40$ & S typhi ViI (Vi) & $42(58 \%)$ & $3(38 \%)$ \\
$<1 / 40$ & S godesburg (control) & $27(37 \%)$ & $5(62 \%)$ \\
$1 / 40$ & S typhi ViI (Vi) & & \\
$1 / 40$ & S godesburg (control) & $4(5 \%)$ & 0 \\
$<1 / 40$ & Styphi ViI (Vi) & \\
$<1 / 40$ & S godesburg (control) & & \\
\hline
\end{tabular}

A titre of $1 / 40$ was considered positive in routine serodiagnosis. flat containing $25 \mathrm{ml}$ nutrient agar. The cell mass was harvested into $15 \mathrm{ml} 2 \%$ (vol/vol) formol saline, washed in saline, and cells resuspended in $15 \mathrm{ml} 2 \%$ (vol/vol) formol saline. This preparation was diluted $\times 10$ in saline for use in the agglutination assay. This standard Widal protocol produced a suspension of formalin fixed bacteria with an absorbance $\left(\mathrm{A}_{621}\right)$ of 0.17 , equivalent to $1.4 \times 10^{9}$ bacteria/ $\mathrm{ml}$. Preparations of $S$ typhi ViI and $S$ godesburg used in our study were standardised to this bacterial density. The Widal assay was performed in 96 well, round bottomed plates (Sero-Wel®; Bibby Sterilin Ltd, Stone, Staffordshire, UK). Sera were initially diluted $(\times 10)$ in saline and used to make a double dilution gradient of $100 \mu 1 /$ well of $1 / 20,1 / 40$, etc. Bacterial suspension $(100 \mu \mathrm{l})$ was added to each well before incubation at $37^{\circ} \mathrm{C}$ for two hours, followed by incubation at $4^{\circ} \mathrm{C}$ overnight. The titre was determined as the serum dilution still giving readily observable agglutination.

SDS-PAGE/IMMUNOBLOTTING

SDS-PAGE and immunoblotting were performed ${ }^{10}$ using proteinase $\mathrm{K}$ digested bacteria, and resultant profiles were either stained for capsular polysaccharide ${ }^{16}$ or used for immunoblotting and reaction with patients' antibodies. For immunoblotting, profiles were reacted with sera $(30 \mu \mathrm{l} /$ lane $)$ and bound antibodies detected with a goat antihuman polyvalent antibody conjugated with alkaline phosphatase (Sigma Chemical Co Ltd). ${ }^{28-10}$

DOT BLOTTING

Whole cell digests of $S$ typhi ViI and $S$ godesburg were applied to nitrocellulose sheets using a range of antigen concentrations and reacted with a dilution gradient prepared from the patients' sera. Antibody-antigen complexes were detected using a goat antihuman polyvalent antibody conjugated with alkaline phosphatase, as described above.

\section{Results}

WIDAL Vi AGGLUTINATION ASSAY

Of the patients culture positive for $S$ typhi, 42 of 73 patients' sera produced a Vi agglutination titre $\geqslant 1 / 40$, and a titre of $<1 / 40$ with the $S$ godesburg bacterial preparation (table 2). Twenty seven of the sera gave titres of $\geqslant 1 / 40$ with both antigen preparations and only four sera gave titres of $<1 / 40$ with both preparations.

Of the 10 sera from patients culture positive for other Salmonella spp, seven gave an agglutination titre of $\geqslant 1 / 40$ with $S$ typh $i$ ViI (table 1 ); however, only two of these gave a titre of $<1 / 40$ with the $S$ godesburg antigen preparation and the patients had been infected with $S$ enteritidis and $S$ javiana. Five patients' sera produced agglutination titres of $\geqslant 1 / 40$ with both antigen preparations (table 1), and only one patient's serum produced agglutination titres of $<1 / 40$ with both bacterial suspensions.

Three of the eight control sera produced an agglutination titre $\geqslant 1 / 40$ with $S$ typh $i$ ViI and a titre of $<1 / 40$ with $S$ godesburg bacterial 
preparations, and five sera gave titres of $\geqslant 1 / 40$ with both antigen preparations (table 2).

SDS-PAGE, IMMUNOBLOTTING, AND DOT BLOTTING

Sera with high titres of agglutinating antibodies to $S$ typh $i$ ViI, but not $S$ godesburg, were used to explore the possible usefulness of SDS-PAGE and immunoblotting, and dot blotting for the detection of the Vi antigen. Whole cell proteinase $\mathrm{K}$ digests of $S$ typhi ViI were applied to SDS-PAGE gels and resultant profiles were stained with alcian blue or reacted with patients' sera by immunoblotting. SDS-PAGE profiles did not stain with alcian blue and patients' antibodies did not bind to these whole cell profiles.

Whole cell digests of $S$ typhi ViI and $S$ godesburg were also reacted with patients sera by dot blotting. Using gradients of antigen concentration and serum dilution, it was not possible to delineate patients' sera from control sera.

\section{Discussion}

The Widal assay, for antibodies to the Vi antigen of $S$ typhi ViI, detected 84 sera with antibody titres equal to or greater than the established cut off dilution value of $1 / 40$. By established criteria, these results would have been indicative of recent or previous exposure to $S$ typhi after either infection, asymptomatic carriage, or vaccination against typhoid. However, the observation that 27 sera produced agglutination titres of $\geqslant 1 / 40$ with both $S$ typhi ViI and $S$ godesburg antigens showed that nonspecific agglutination could occur and illustrated the importance of including an unrelated antigen in the Widal assay.

The Widal assay also detected high concentrations of antibodies to $S$ typhi ViI in eight control sera, although only three of these had titres of $<1 / 40$ to $S$ godesburg. The basis for these reactions was not known and they might have been the result of an infection with $S$ typhi or previous vaccination against typhoid, or other non-specific factors.

Seven patients, infected with $S$ bareilly, $S$ enteritidis, $S$ javiana, $S$ mbandaka, $S$ saint paul, and $S$ stanley, produced serum agglutination titres of $\geqslant 1 / 40$ with the $S$ typhi ViI antigen, and would also have been considered as seropositive for Vi. Only two patients, one infected with $S$ enteritidis and one with $S$ javiana, had serum agglutination titres of $\geqslant 1 / 40$ with $S$ typhi ViI and $<1 / 40$ with $S$ godesburg, and they had been infected with $S$ enteritidis and $S$ javiana. These bacteria share the LPS antigens 1,9,12 but not the ViI antigen with $S$ typhi and the basis of the agglutination remains unknown.

The Widal assay described here detected only 42 sera with high concentrations of antibodies to $S$ typhi ViI Vi antigen and titres below 1/40 for the $S$ godesburg antigen, even though all 73 sera had been from patients infected with $S$ typhi. This showed that not all patients infected with $S$ typhi will produce serum antibodies to the $\mathrm{Vi}$ antigen. A previous study ${ }^{9}$ found that approximately one third of patients infected with $S$ typhi did not produce antibodies to the $\mathrm{H}=\mathrm{d}$ flagellar antigen, and this illustrates the importance of using more than one antigen for the serodiagnosis of infections with $S$ typhi.

The techniques of SDS-PAGE and immunoblotting could not be used to detect antibodies to the $\mathrm{Vi}$ antigen because the capsular polysaccharide of $S$ typhi ViI did not enter the polyacrylamide gel, probably because the capsular material had a molecular structure too large to allow entry into the acrylamide matrix. Dot blotting also failed to differentiate patients' sera from control sera, and it was concluded that only the agglutination assay could detect antibodies thought to be specific for the Vi antigen.

From this and others studies, ${ }^{8-10}$ we conclude that for the serodiagnosis of infection with $S$ typhi, patients' antibodies to the $\mathrm{O}=9,12 \mathrm{LPS}$ and $\mathrm{H}=\mathrm{d}$ flagellar antigens should be detected by immunoblotting, and not with the Vi antigen based Widal agglutination test. The results of these immunoassays must be considered in the light of patients' clinical details and any history of vaccination.

1 Rowe B, Hall MLM. Kaufmann-White scheme 1989. London: Public Health Laboratory Service, 1989.

2 Felix A. Standardising of diagnostic agglutination tests. Bull World Health Organ 1950;2:643-9

3 Hoffman SL, Flanigan, TP, Klaucke D, et al. The Widal slide agglutination test, a valuable rapid diagnostic test in typhoid fever patients at the infectious diseases hospital of Jakarta. Am f Epidemiol 1986;123:869-75.

4 Levine MM, Grados O, Gilman RH, et al. Diagnostic value of the Widal test in areas endemic for typhoid fever. $A m \mathcal{F}$ Trop Med Hyg 1978;27:795-800.

5 West B, Richens JE, Howard PF. Evaluation in Papua New Guinea of a urine coagglutination test and a Widal slide grglutination test for rapid diagnosis of typhoid fever. Trans R Soc Trop Med Hyg 1989;83:715-17.

6 Buck RL, Escamilla J, Sangalang RP, et al. Diagnostic value of a single pre-treatment Widal test in suspected enteric fever cases in the Philippines. Trans $R$ Soc Trop Med Hyg 1987;81:871-3.

7 Pang T, Puthucheary SD. Significance and value of the Widal test in the diagnosis of typhoid fever in an endemic area. F Clin Pathol 1983;36:471-5.

8 Chart H, Ward, LR, Rowe B. Serological response of patients with clinical typhoid. Serodiagnosis and Immunotherapy in Infectious Disease 1995;7:30-3.

9 Chart H, Rowe B, Cheesbrough JS. Serological response of patients infected with Salmonella typhi. F Clin Pathol 1997; 50:944-6.

10 Chart H, Ward, LR, Rowe B. An immunoblotting procedure comprising $\mathrm{O}=9,12$ and $\mathrm{H}=\mathrm{d}$ antigens as an alternative to the Widal agglutination assay. F Clin Pathol 1998;51:854-6.

11 Bhatnagar SS. Vi agglutination in the diagnosis of typhoid fever and the typhoid carrier condition. BMF 1938;2:11958.

12 Bhatnagar SS, Speechly CGJ, Singh M. A Vi variant of Salmonella typhi and its application to the serology of typhoid fever. Fournal of Hygeine Cambridge 1938;38:663-72.

13 Chart H, Waghorn, DJ, Rowe B. Serological detection of patients infected with Salmonella enteritidis. Serodiagnosis patients infected with Salmonella enteritidis. Serodiag

14 Chart H, Waghorn, DJ, Rowe B. Serological response of patients infected with Salmonella enteritidis PT4. Serodiagnosis and Immunotherapy in Infectious Disease 1994;6:21-4.

15 Chart H, Rowe B. A simple dot immunoassay for detecting antibodies to the lipopolysaccharide of verocytotoxinproducing Escherichia coli in patients with haemolytic uraemic syndrome. F Microbiol Method 1997;28:85-8.

16 Møller $\mathrm{J}$, Heinegård $\mathrm{D}$, Poulsen $\mathrm{JH}$. Combined alcian blue and silver staining of subnanogram quantities of proteoglycans and glycosaminoglycans in sodium dodecyl sulphatepolyacrylamide gels. Anal Biochem 1993;209:169-75. 